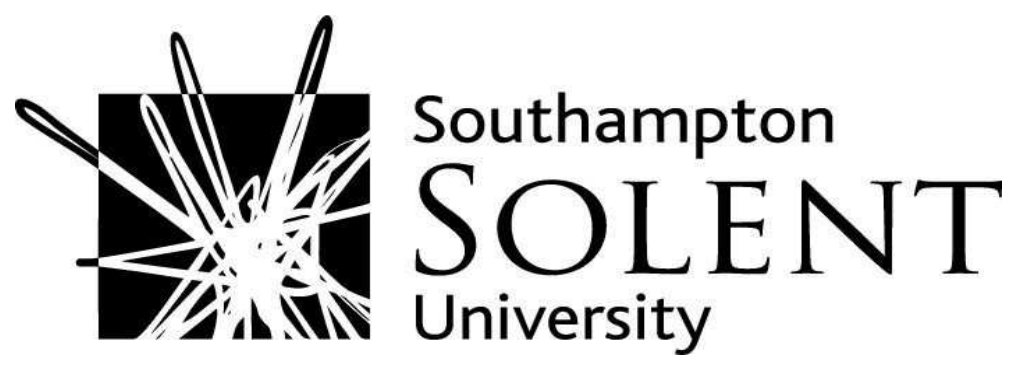

Turner, Mark. (2012). Modern 'live' football: moving from the panoptican gaze to the performative, virtual and carnivalesque. Sport in Society, 1 June 2012, ifirst, pp. 1-9

Downloaded from http://ssudl.solent.ac.uk/2334/

Usage Guidelines

Please refer to usage guidelines at http://ssudl.solent.ac.uk/policies.html or alternatively contact ir.admin@solent.ac.uk. 
This article was downloaded by: [Southampton Solent University], [Mark Turner] On: 22 June 2012, At: 08:43

Publisher: Routledge

Informa Ltd Registered in England and Wales Registered Number: 1072954 Registered office: Mortimer House, 37-41 Mortimer Street, London W1T 3JH, UK

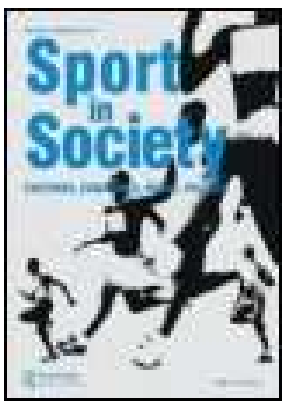

\section{Sport in Society: Cultures, Commerce, Media, Politics}

Publication details, including instructions for authors and subscription information:

http:// www.tandfonline.com/loi/ fcss20

\section{Modern 'live' football: moving from the panoptican gaze to the performative, virtual and carnivalesque}

Mark Turner ${ }^{a}$

a Faculty of Sport Business and Enterprise, Southampton Solent University, Southampton, UK

Available online: 01 Jun 2012

To cite this article: Mark Turner (2012): Modern 'live' football: moving from the panoptican gaze to the performative, virtual and carnivalesque, Sport in Society: Cultures, Commerce, Media, Politics, DOI:10.1080/ 17430437.2012.690404

To link to this article: http:/ / dx.doi.org/ 10.1080/ 17430437.2012.690404

\section{iFirst}

PLEASE SCROLL DOWN FOR ARTICLE

Full terms and conditions of use: http://www.tandfonline.com/page/terms-and-conditions

This article may be used for research, teaching, and private study purposes. Any substantial or systematic reproduction, redistribution, reselling, loan, sub-licensing, systematic supply, or distribution in any form to anyone is expressly forbidden.

The publisher does not give any warranty express or implied or make any representation that the contents will be complete or accurate or up to date. The accuracy of any instructions, formulae, and drug doses should be independently verified with primary sources. The publisher shall not be liable for any loss, actions, claims, proceedings, demand, or costs or damages whatsoever or howsoever caused arising directly or indirectly in connection with or arising out of the use of this material. 


\title{
Modern 'live' football: moving from the panoptican gaze to the performative, virtual and carnivalesque
}

\author{
Mark Turner* \\ Faculty of Sport Business and Enterprise, Southampton Solent University, Southampton, UK
}

\begin{abstract}
Drawing on Redhead's discussion of Baudrillard as a theorist of hyperreality, the paper considers the different ways in which the mediatized 'live' football spectacle is often modelled on the 'live' however eventually usurps the 'live' forms position in the cultural economy, thus beginning to replicate the mediatized 'live'. The blurring of the 'live' and 'real' through an accelerated mediatization of football allows the formation of an imagined community mobilized by the working class whilst mediated through the sanitization, selling of 'events' and the middle classing of football, through the re-encoding of sporting spaces and strategic decision-making about broadcasting. A culture of pub supporting then allows potential for working-class supporters to remove themselves from the panoptican gazing systems of late modern hyperreal football stadia and into carnivalesque performative spaces, which in many cases are hyperreal and simulated themselves.
\end{abstract}

\section{Introduction}

This paper explores the relationship between the experience of watching the 'live' football event at the stadium in person and watching the mediatized 'live' ${ }^{1}$ by sports media technology such as television and the Internet. By modern here, I refer to the current places and spaces in which premiership football operates today.

Drawing on 'live' performance cultural theorists from theatre and popular music such as Auslander, ${ }^{2}$ the paper also aims to critique the status of 'live' football performance in a mass-media-dominated culture and considers whether the encroachment of sports media technology on the 'live' event itself has led to the middle classing of football whilst affecting the level of 'liveness' of both the 'real' 'live' event and the mediatized 'representation' or 'version', thus subsequently producing an almost hyperreal, virtual, simulated 'live'. 3

Taking the specific case of the 'pub as a virtual football fandom venue', ${ }^{4}$ the discussion will then critically consider how this perhaps acts as the 'optimal sporting experience in late modernity', ${ }^{5}$ whereby this culture may have reproduced and recovered a lost traditional working-class community who have, in some cases, been priced out of Premier League football. Pub spectatorship then produces a parody of the 'real' 'live' and thus leaving 'those absent from the stadium to be always right' ${ }^{6}$

\section{Middle classing of football spaces}

From the early development of football through to the modern era of the 1960s and up to the early 1990s, there remained a strong hard proletarian masculine identity on the terraces at the 'live' event itself that often developed into social sporting communities. This 'terrace

*Email: turnerm@edgehill.ac.uk 
culture' and the 'obsessive fan' became then the dominant focus over the 'ordinary supporter' or 'casual television viewer' (Ferris in Redhead, 1997, 29).

Both Whannel ${ }^{7}$ and Boyle and Haynes ${ }^{8}$ map out the relationship between early 'live' football broadcasting and highlight programmes and the construction of audiences and identities within this process. Whilst this paper is not concerned with the historical development of the modern 'live' mediatized football event, it is important to set the context for what has been the most critically important development in football and popular culture since the league was established in 1888; that being the formation of the Premier League and its relationship with the Rupert Murdoch-owned BSkyB satellite broadcasting service in 1992. ${ }^{9}$

The 'establishment of the Premier League and revamping of the European Cup as the Champions League also increased the spectacularisation of football, where new, more affluent customers were attracted and admission prices rose which led to many poorer supporters being excluded'. ${ }^{10}$

Weed correctly notes that 'according to the journalist Simon Freeman, football was seen by BSkyB as the hook by which people on lower incomes could be persuaded to sign up to a satellite TV subscription'. ${ }^{11}$ This period then laid the foundation for an accelerated change in the whole way in which people were to live and experience the 'live' football event. The modern $3 \mathrm{pm}$ Saturday afternoon kick off would eventually make way for a series of alternative times to coincide with sky sports marketing and programming, where the traditional proletarian social experience and ritual of the Saturday 'few pints at the pub' before the match would, a decade later, make way for what was on one specific occasion, an 11.15 am Sunday game between Manchester City and Everton, which was, and still is, the earliest kick-off in the Premiership's history. ${ }^{12}$

Also around the early 1990s, a further significant change took place around the experience of the 'live' event itself, which has been referred to by some as the 'sanitisation of football grounds, specifically the Premier League, as a result of the changes brought about by the 1990 Taylor Report on the safety of sports stadia after the Hillsborough tragedy. ${ }^{13}$ This change in how people watched the event 'live' through the introduction of all seating stadiums took place during a dynamic accelerating process.

Examples of other specific changes included the migration of coaching and playing talent from all over the world into the English game, the increase and multiple choice of 'live' televised games and, of course, the development of neoliberal policies within the business of football, which expanded the game both globally and economically. ${ }^{14}$ As Redhead discussing Paul Virilio's work as a theorist of 'accelerated culture' notes that the era of twenty-first-century modernity and the 'age of the accelerator' might be best described as 'accelerated modernity'. ${ }^{15}$ Thus, any discussion of the modern 'live' football spectacle might be best understood within an accelerated 'live' modernity context.

This historical context suggests that the 'live' modern football event itself, whether it be at the stadium or broadcasted via sports television and other forms of multimedia technology, has undergone a rapid accelerated cultural change, and thus to understand the phenomenon of mass-media-dominated culture and these changes in spectatorship communities and experiences, we must recognize this acceleration of 'live' modernity before discussing the issue of realism within the current spaces and places of the 'live' football event.

\section{Relationship between the 'live' event and the mediatized 'live'}

What has become of the 'live' football event itself at the stadium? And what constitutes this 'live' experience? 
Before the acceleration of 'live' modernity began to rapidly increase post-1992, the experience of watching the modern 'live' football event at the stadium was more than just a 'viewing' or 'spectating' of the 'live' spectacle. The 'live' event was often a proletarian pilgrimage to a magical space, where a local and shared community experience could take place. Many thousands of people from the same town, village, city or even country would gather together to witness and participate in this predominantly male, heteronormative, masculine community.

Weed discusses the nature of the 'live' sport spectating experience drawing on concept of the 'leisure pursuit of being there'. ${ }^{16}$ What is interesting to note here is the idea that, whilst experiencing football 'live' at the stadium is of course concerned with the immediate excitement of witnessing the event unfold in 'real time', this 'live presence' also plays an important role in being able to 're-call' and 're-tell' the experience after the event. It is also interesting to consider here the context of 'liveness' and theatre/music performances, where Auslander discusses the 'socio-cultural' value attached to 'live' presence where being able to "say one saw a particular musician, actor or gig "live", enables one to perhaps gain social prestige'. ${ }^{17}$

MacCannell's idea of 'returning' is a further significant part of the 'live' event experience in person, and that the 'being there' at the football stadium to see the drama unfold is one of the features of the 'live' event itself which makes it distinct from not being there, or perhaps witnessing it 'live' on television or recorded at a later time. ${ }^{18}$ This idea is also discussed within the context of television and space, where to watch an event 'live' at a distance and not in person at the stadium, for example on TV, prevents an individual to stand as a witness to history because they lack 'privileged raw, authentic proximity to facts'. 19

Furthermore, Boden and Molotch have suggested that the excitement and witnessing of the 'live' event itself holds a further important feature, that being 'the compulsion of proximity', ${ }^{20}$ where to fully experience the event unfold 'live', spectators are required to be in the 'company of others', for example, a physical presence at the stadium with other supporters.

Within the field of theatre and drama studies, Grotowski on the subject of participation between the actor and audience, in this case the live event and spectator, suggested that the actual participation should be 'somatic' and 'bodily', ${ }^{21}$ and thus to really experience the event 'live', the actors (live event unfolding) should perform (or be performed) amongst the audience and that the audience should participate physically.

This idea of spectating at the 'live' event itself for many supporters is an actual physical bodily experience where they believe that not only are they potentially able to influence a result, ${ }^{22}$ but the actual 'living' of the event and being able to 're-tell' and 're-call' it is heightened by the very fact that the experience is 'bodily' and 'somatic'. The 'live' football stadium spectacle becomes then an example of Stanislavski's 'dramatic theatre' where the 'live' sporting audience's participation becomes both physical and psychological, in that the audience believes through the convincing 'realism' of performance, for example, the songs, chants, physical movements, emotions and passion, that what they are in fact watching is 'real' and 'live', and thus 'live' spectatorship or audience can only be participating in nature. ${ }^{23}$

\section{The football fan as 'post-tourist' and the self-conscious reflexivity of the 'live'}

Since 1992 and the acceleration of 'live' modernity however, the experience for many supporters at the 'live' event has changed significantly. Redhead describes in detail this 
change in fandom culture that he calls 'post-fandom', where a distinction has occurred between the 'direct' experience of the 'live' spectacle and the 'experience of the game being always mediated'. ${ }^{24}$ What has literally taken place during the acceleration of 'live' modernity at the event is the shrinking of the differences between original and modern notions of 'live' spectatorship that included terrace culture and a more intense 'Grotowski' experience, and the 'live' mediatized version on television.

Redhead suggests that there is now a similarity between watching instant replays on giant video screens at the 'live' event to watching these replays on television. As a result, there has also been a shrinking of the differences between the 'passive' and 'participatory' actions of spectators. ${ }^{25}$ Often during terrace culture, fans would congregate to specific areas of the stand to obtain a better view of a particular goal to which their team were attacking, or to be physically and fanatically part of an identifiable atmosphere or group.

Since the development of post-fandom culture however, the participatory has now become intertwined with the passive, where in most modern all-seater stadiums spectators from different stands are able to see the whole pitch and event perfectly from similar angles and become part of the 'post-tourist' ${ }^{26}$ culture of 'grazing' at the event itself, through the viewing of action replays and in some cases, for example, at the home of Tottenham Hotspur F.C., White Hart Lane, the 'live' event itself on a giant TV screen at the same time the 'live' event unfolds on the pitch. This global post-fandom culture perhaps took its most significant status during the USA '94 World Cup where the increase in consumption of the global 'live' mediatized event led to the increase in passive rather than participatory audiences. ${ }^{27}$

The acceleration of 'live' modernity at the event has also produced a more cinematic consumer experience than that of the previous terrace culture, where the stadium has become an 'extension of the living room' and thus developing an 'armchair fan culture', ${ }^{28}$ through the constant supply of food and drink and the cost and style of the experience.

Auslander has discussed sporting events within the context of 'liveness' in a mediatized culture and its effect on the 'live' event, suggesting 'spectators now watch significant portions of the games they are attending on giant video screens, where the rhetoric of mediatisation embedded in such devices as the instant replay, the simulcast and the close up, are now constitutive of the live event itself' ${ }^{29}$

The mediatization of the 'live' event has a further relationship with the 'live' event itself, where spectators at the match, for example, 'are not only seeing performances that resemble mediatised ones as closely as possible, but are apparently modelling their responses to the live event on those expected of them by television'. ${ }^{30}$

Taking this phenomenon further then, Redhead has offered a fascinating insight into the application of Paul Virilio to the study of the 'live' event spectacle and has perhaps captured this accelerated change most accurately. As he notes, 'spectators at a Premiership match today constantly watch from an inert sedentary position in an accelerated, and accelerating, spectacle flash by in a blur'. ${ }^{31}$ Furthermore, in discussing the relationship between the 'live' event experience and the mediatized representation of it, he suggests that the "way the spectator watching the game "live" at the stadium, actually sees the speeding spectacle, is conditioned by decades of watching such matches "live" on television, sofa surfing in the sedentary comfort of the armchair, an example of Virilio's pathological fixedness or polar inertia'. ${ }^{32}$

What we witness here then is not only a shrinking of the differences between the 'passive' and the 'participatory' at the 'live' event, but also a paradoxical relationship between the 'live' event itself at the stadium and the mediatized 'live'. Furthermore, as we are 'born into post-fandom' and the 'fragmentary, self-conscious, reflexive, mediated 
and artistic become more pervasive', so too does the 'self-conscious' experience of the mediated 'live' event. ${ }^{33}$

\section{Baudrillard and the hyperreality and simulation of the 'live'}

The relationship between the 'live' event and the mediatized 'live' also raises the question of realism. Redhead's discussion of Baudrillard 'muses about the extent to which media coverage displaces the real event' and how the 'real referent has disappeared over recent years where audiences both "live" at the event and watching it "live" on TV have been transformed by the increasing domination of the mental screen'. ${ }^{34}$

Giulianotti discusses Baudrillard's notion of hyperreality and the role in which the media plays in the confusion and simulation of reality. ${ }^{35}$ The mediatized 'live' event, according to Baudrillard, then attempts to reproduce the 'realism' of the 'live' event itself in simulated form, before the actual 'live' event can materialize. ${ }^{36}$ This acceleration of 'live' modernity takes on a virtual life where the entire 'live' experience of the event is reformulated and simulated by multiple camera angles.

There is increasing evidence of the growing hyperrealism within the passive experience of the 'live' event, where in some cases actual crowd participation and atmosphere have been simulated, for example, the simulation of a whole 'end' of terrace culture at Highbury during rebuilding work in the early 1990s. ${ }^{37}$ Furthermore, during the 2006/2007 season at Manchester City's Eastlands stadium, the author personally experienced a simulated crowd noise being broadcast around the North Stand, producing a hyperreal atmosphere to combat the lack of 'real' singing amongst passive supporters.

As the acceleration of 'live' modernity continues, Baudrillard 'anticipates the day when football matches will be played before empty stadiums where spectators decide to watch the match on TV at home, consuming the hyperrealism of pornographic sporting information in a virtual experience of directorial technological control'. ${ }^{38}$ In a sense then, the mediated 'live' almost becomes a 'third order of simulacra' replacing the original real 'live' event itself, ${ }^{39}$ simulating an almost 'realer than real' world in which the event is situated. ${ }^{40}$

Perhaps the most telling contribution of Baudrillard to the discussion of the 'live' event and the mediatized 'live' is his idea of the 'live' becoming so 'mediatised and hyperreal that it can be said to have not taken place'. ${ }^{41}$ What is suggested here is the idea that we can only understand the 'live' event to have taken place, through our understanding of the context in which it is transmitted in 'real time' within the 'live' mediatized event. ${ }^{42}$ As the football 'live' event is controlled and organized around 'commercials and television deadlines' mediated within discourse, the event becomes less about the clash between the players, and more about the 'surgical execution of pre-programmed, simulated game strategies' ${ }^{43}$

This virtual mediatized 'live' provides a 'pornography of sport' in which Sky Sports interaction, numerous choice of angles and audio systems produce a 'visual excess of reality that no spectator "live" at the event enjoys'. ${ }^{44}$ However, even for the most passive people at the event itself within accelerated 'live' modernity, it has become a televised, rather than an actual participatory experience.

What for the future then? Giulianotti has already noted that modern computer technology can simulate games by using 'old video footage of matches to create new ones' and that 'children are now playing football on their television screens through their game consoles rather than in the streets'. ${ }^{45}$ This is perhaps a microcosm of Baudrillard's vision, in that 'by the time of the European championships in 2008, fans will not need to travel to the tournament to enjoy the sensory pleasures of being there ${ }^{46}$ rather the spectator will be left to enjoy and 'partake in, an interactive experience as if they are there in the stadium'. ${ }^{47}$ 


\section{The 'live' culture of pub supporting}

A recent cultural phenomenon has developed, which perhaps reveals a further interesting relationship between the passive and the participatory, and the 'real' and 'hyperreal'. This phenomenon is what Weed has referred to as the 'culture of pub supporting' ${ }^{48}$ where spectators of 'live' football have begun to recognize the 'pub not only as a place to socialise before the match but as an actual virtual football fandom venue itself, which offers an alternative to being at the "live" event in person'.

Redhead was quick to recognize the early development of this culture when he suggested that 'one significant response to the Sky takeover of English football in the early 1990s has been for fans to congregate in large numbers across the country in bars, which have Sky TV at times of live matches, and that this "pub culture" has in effect replaced the yesteryear participatory terrace culture'. ${ }^{49}$

What the mediatized 'live' has produced then is an opportunity to play on the subtle distinction between the real and hyperreal, where the "cheap availability' ${ }^{50}$ for workingclass supporters, who have been priced out of becoming part of the post-fan culture at the 'simulated' 'live stadium event, to watch the game for free, has allowed them to construct and imagine a community ${ }^{51}$ and social experience, which has been lost to some degree, during accelerated 'live' modernity and post-fan culture.

During traditional open 'terrace culture', fans were able to 'choose where they watched the game, which some believed to have been vital to the creation of atmosphere at the 'live' event, ${ }^{52}$ and whilst the 'sanitized' new stadium experience may have 'destroyed this traditional atmosphere, ${ }^{53}$ fans are now able to choose from a number of pub venues, at which to watch a particular game. As Brimson in Weed explains, 'it is cheaper and easier to simply go down the pub and watch the game while having a few beers, where in most cases it will be with the same group of geezers and so the atmosphere will be as good if not better than at the actual game'. 54

What is perhaps interesting to note here is whilst Redhead has correctly indicated that such 'pub culture' has developed out of necessity in a sense, where a 'lack of access to 'live televised matches at home and at the event' has meant supporters having to look elsewhere, ${ }^{55}$ the "culture of pub supporting and its predominantly "proletarian" experience have now developed into an activity that is attractive in its own right'. ${ }^{56}$ More importantly, the mediatized 'live' at the pub venue now often streams English football matches from European channels, thus presenting the fan with the option of watching a match 'live' that may not be shown on TV at all.

As a result then, the 'culture of pub supporting' reveals some of the key features identified by Weed as being integral to the 'real' 'live' event experience, such as the 'shared proletarian communal experience' and 'collective enjoyment," 57 that have decreased within the more individual and simulated cinematic experience evident within the new middle classing of Premier League football. The significance of this "virtual fandom site ${ }^{58}$ is that the pub in a sense becomes almost a site of protest in which the collective proletariat reproduce the community taken away from them by the bourgeois authorities. As supporters attend the pub as a virtual alternative to being present at the 'live' event, they socially construct an imagined community ${ }^{59}$ that in some cases allows for socialization processes with other fans whom they have never met before. Equally, these fans are also aware that they are part of a broader imagined community of fellow working-class supporters who are attending other pubs across the country. 
Weed also notes that such a site of protest could provide potential for 'virtual football hooliganism' and 'virtual football violence', ${ }^{60}$ which in some cases has already occurred, specifically during England football World Cup matches.

Finally, Bale in Brown draws our attention to a further recent example of the 'virtual fandom' phenomenon during accelerated 'live' modernity, in his discussion of Danish football and folk tradition. Recalling a match between Denmark and Germany in Copenhagen, he describes the open park land space known as 'Faelled', where a huge television screen was erected amongst thousands of fans producing a carnival atmosphere ${ }^{61}$, standing in opposition to the panopticized ${ }^{62}$ confinement of modern stadia and that such experience was perhaps the 'optimal sporting experience for late modernity; an incongruous juxtapositioning of late-modern and folk traditions' ${ }^{63}$

\section{Concluding thoughts}

This paper has discussed the 'live' football event within accelerated modernity and its relationship with post-fandom culture and the hyperreal simulated style of the mediatized 'live'. By understanding the development of accelerated 'live' modernity and the growing influence of global media communications and technologies, we are able to recognize the post-modern way in which the experience of the 'real', 'live' event at the stadium and the 'hyperreal' mediatized 'live' have become so mixed up and intertwined that in many ways they now cannot be understood independent of each other.

Drawing on Baudrillard and Virilio, the paper has demonstrated different ways in which the mediatized form is often modelled on the 'live' form, but eventually usurps the 'live' forms position in the cultural economy, and thus the 'live' form begins to replicate the mediatized 'live'. ${ }^{64}$

In recognizing the paradoxical relationship between the 'live' and mediatized 'live' and traditional terrace culture and post-fandom culture, the paper has touched upon the new interesting phenomenon of 'pub supporting culture' that experiences both the virtual, almost simulacra of the mediatized 'live', whilst retaining and recovering some of the participatory and shared community experiences of the traditional 'live' event itself.

This modern image technology allows both the traditional and post-fan to survey the 'real' world whilst maintaining a 'Brechtian' critical distance ${ }^{65}$ through the style of virtual and pub communities, that somehow denies its reality. ${ }^{66}$ The culture of pub supporting then allows supporters to playfully parody the 'real' 'live' experience through the social interaction and sharing of an imagined community, whilst still being aware of the hyperreality and simulation of the mediatized 'live' on the large screen. Perhaps it is those absent from the stadium who converge to the 'live' pub, who are actually always right.

\section{Acknowledgements}

Steve Redhead for his general helpful advice and support.

\section{Notes}

1 Auslander, Liveness.

2 Ibid.

${ }^{3}$ See discussion of Baudrillard in Giulianotti, Sport: A Critical Sociology.

${ }^{4}$ Weed, 'Pub as a Virtual Football Fandom Venue?'

${ }^{5}$ Bale, 'Virtual Fandoms', 275.

${ }^{6}$ Virilio's concept of 'those absent from the stadium are always right' in Redhead, Paul Virilio, Theorist for an Accelerated Culture. 
${ }^{7}$ Whannel, Fields in Vision; Media Sport Stars Masculinities and Moralities.

${ }^{8}$ Boyle and Haynes, Power Play, Sport, the Media and Popular Culture.

9 Emery and Weed, 'Fighting for Survival?'

${ }^{10}$ Whannel, Fields in Vision, 38.

11 Weed, 'Pub as a Virtual Football Fandom Venue?' 401.

12 See Sky Sports Football News Match Report, Manchester City vs. Everton, 2 October 2005.

13 Weed, 'Pub as a Virtual Football Fandom Venue?' 401.

14 Giulianotti, Sport: A Critical Sociology.

15 Redhead, Paul Virilio Reader, 28.

16 Discussion of Baines in Weed, 'Pub as a Virtual Football Fandom Venue?'

17 Auslander, Liveness, 66.

18 MacCannell's discussion of 'returning' in Weed, 'Pub as a Virtual Football Fandom Venue?'

19 Peters in Marriott, Live Television, 111.

${ }^{20}$ Boden and Molotch in Weed, 'Pub as a Virtual Football Fandom Venue?' 407.

${ }^{21}$ Discussion of Grotowski's acting style in Mitter, Systems of Rehearsal, Stanislavski, Brecht, Grotowski and Brook.

22 Whannel, Media Sport Stars Masculinities and Moralities.

23 Discussion of Stanislavski's method in Mitter, Systems of Rehearsal, Stanislavski, Brecht, Grotowski and Brook.

${ }^{24}$ Redhead, Post-Fandom and the Millennial Blues, 30.

25 Ibid.

${ }^{26}$ Ury in Redhead, Post-Fandom and the Millennial Blues, 29.

27 Ibid.

28 Boyle and Haynes, Power Play, Sport, the Media and Popular Culture.

29 Auslander, Liveness, 25.

${ }^{30}$ Ibid.

31 Redhead, 'Those Absent from the Stadium are Always Right', 13.

32 Ibid.

${ }^{33}$ Redhead, Post-Fandom and the Millennial Blues, 29.

${ }^{34}$ See discussion of Baudrillard in Redhead, Post-Fandom and the Millennial Blues, 42.

${ }^{35}$ Giulianotti, Sport and Modern Social Theorists, 234.

${ }^{36}$ Bogart in Giulianotti, Sport and Modern Social Theorists, 234.

37 Watt in Redhead, Post-Fandom and the Millennial Blues, 51.

${ }^{38}$ Giulianotti, Sport and Modern Social Theorists, 234.

39 Baudrillard, Simulacra and Simulation.

${ }^{40}$ See discussion of Baudrillard in Giulianotti, Sport: A Critical Sociology, 185.

${ }^{41}$ See discussion of Baudrillard in Redhead, Post-Fandom and the Millennial Blues, 51.

42 See discussion of Baudrillard in Giulianotti, Sport and Modern Social Theorists, 235.

43 Ibid.

${ }^{44}$ Baudrillard in Giulianotti, Sport: A Critical Sociology, 185.

45 Giulianotti, Football: A Sociology of the Global Game, 84.

46 Ibid.

47 Ibid.

48 Weed, 'Pub as a Virtual Football Fandom Venue?'

49 Redhead, Post-Fandom and the Millennial Blues, 30.

50 Weed, 'Pub as a Virtual Football Fandom Venue?' 401.

51 Anderson, Imagined Communities.

52 Ibid.

53 Ibid.

54 Ibid

55 Redhead, Post-Fandom and the Millennial Blues.

56 Weed, 'Pub as a Virtual Football Fandom Venue?' 403.

57 Ibid.

58 Bale in Brown, Fanatics! Power, Identity and Fandom in Football.

59 Anderson, Imagined Communities.

${ }^{60}$ Weed, 'Pub as a Virtual Football Fandom Venue?' 411.

${ }^{61}$ See Bakhtin's notion of the 'canivalesque' in 'Rebelais and his world'.

${ }^{62}$ See discussion of the panoptican in Foucault, Discipline and Punish. 
${ }^{63}$ Bale in Brown, Fanatics! Power, Identity and Fandom in Football, 275.

64 Auslander, Liveness.

65 Discussion of Brecht in Mitter, Systems of Rehearsal, Stanislavski, Brecht, Grotowski and Brook.

${ }^{66}$ Robins, 'Into the Image.

\section{References}

Anderson, B. Imagined Communities: Reflections on the Origin and Spread of Nationalism. London: Verso, 1991.

Auslander, P. Liveness: Performance in a Mediatized Culture. 2nd ed. London: Routledge, 2008.

Baines, S. 'Sports Tourism: The Leisure Pursuit of Being There'. Paper presented at the 4th World Leisure and Recreation Association World Congress, Cardiff, July, 1996.

Bakhtin, M. Rebelais and His World. Bloomington: Indiana University Press, 1941.

Bale, J. 'Virtual Fandoms: Futurescapes of Football'. In Fanatics! Power, Identity and Fandom in Football, edited by A. Brown. London/New York: Routledge, 1998.

Baudrillard, J. Simulacra and Simulation (The Body in Theory: Histories of Cultural Materialism). Michigan: University of Michigan Press, 1994.

Boyle, R., and R. Haynes. Power Play, Sport, the Media and Popular Culture. Essex: Pearson Education.

Brimson, D. The Geezers Guide to Football: A Lifetime of Lads and Lager. London: Mainstream, 1998.

Emery, R., and M.E. Weed. 'Fighting for Survival? The Financial Management of Football Clubs Outside the Top Flight in England'. Managing Leisure 111, no. 1 (2006): 1-21.

Ferris, K. Football Fanatic. London: Two Heads, 1995.

Foucault, M. Discipline and Punish: The Birth of the Prison. New York: Random House, 1977.

Giulianotti, R. Football: A Sociology of the Global Game. Cambridge: Polity Press, 1999.

Giulianotti, R. Sport and Modern Social Theorists. Hampshire: Palgrave Macmillan, 2004.

Giulianotti, R. Sport: A Critical Sociology. Cambridge: Polity Press, 2005.

MacCannell, D. Tourist or Traveller? London: BBC Education, 1996.

Marriott, S. Live Television: Time, Space and the Broadcast Event. London: Sage, 2007.

Mitter, S. Systems of Rehearsal, Stanislavski, Brecht, Grotowski and Brook. London/New York: Routledge, 1992.

Redhead, S. Post-Fandom and the Millennial Blues. London/New York: Routledge, 1997.

Redhead, S. Paul Virilio, Theorist for an Accelerated Culture. Edinburgh: Edinburgh University Press, 2004.

Redhead, S. The Paul Virilio Reader. Edinburgh: Edinburgh University Press, 2004.

Redhead, S. 'Those Absent from the Stadium are Always Right'. Journal of Sport and Social Issues 31, no. 3 (2007): 226-41.

Sky Sports Football News Match Report. 'Manchester City vs. Everton'. October 2, 2005, http:// www.skysports.com/football/match_report/0,19764,11065_2561819,00.html.

Ury, J. The Tourist Gaze. London: Sage, 1988.

Weed, M. 'The Pub as a Virtual Football Fandom Venue: An Alternative to "Being there"?' Soccer and Society 8, no. 2-3 (2007): 399-414.

Whannel, G. Fields in Vision: Television Sport and Cultural Transformation. London: Routledge, 1992.

Whannel, G. Media Sport Stars Masculinities and Moralities. London/New York: Routledge, 2002. 